\title{
Pengaruh E-WOM, Brand Image dan Brand Trust Terhadap Keputusan Konsumen (Studi Kasus Pada Lembaga Kursus Fajar English Course Pare Kediri)
}

\author{
Muhammad Dian Ruhamak ${ }^{1}$, Afif Nur Rahmadi ${ }^{2}$ \\ Universitas Kadiri ${ }^{1}$, Universitas Kadiri ${ }^{2}$ \\ dianru@unik - kediri.ac. id ${ }^{1}$, afifnur@unik - kediri. ac. id ${ }^{2}$
}

\begin{abstract}
This study aims to determine the effect of e-wom variables, brand image and brand trust on consumer decisions in institutions of the English course pare-kediri dawn courses. The population in this study were all consumers of English course dawn courses in August-September 2019 of 89 respondents, because less than 100 then the whole was taken to be sampled. Methods of data analysis using the validity and reliability of the questionnaire, multiple regression analysis, $f$ and $t$ test and the coefficient of determination. From the test results obtained e-wom variables, brand image and brand trust simultaneously have a positive and significant effect on consumer decisions with a value of fcount $41.919>2.71$ ( $f$ count) and a significance value of 0.000. Partially e-wom and brand image have a positive and significant effect on consumer decisions with a tcount of $3.795>1.99,5.714>1.99$ and a significance of 0.000. While brand trust is negative and does not have a significant effect on consumer decisions with consumer values, this is based on test results that show a t-value of $1.625<t$ table 1.99 and a significance value of 1.08. Brand image has the most dominant influence on consumer decisions because it has the most influence.
\end{abstract}

Keywords: e-wom, brand image, brand trust, consumer decision

\begin{abstract}
Abstrak
Penelitian ini bertujuan untuk mengetahui pengaruh variabel e-wom, brand image dan brand trust terhadap keputusan konsumen pada lembaga kursus fajar English course pare kediri. Populasi dalam penelitian ini adalah seluruh konsumen lembaga kursus fajar English course pada bulan agustus-september 2019 sejumlah 89 responden, oleh karena kurang dari 100 maka keseluruhan diambil untuk dijadikan sampel. Metode analisis data menggunakan uji validitas dan reliabilitas kuesioner, analisis regresi berganda, uji f dan t serta koefisien determinasi. Dari pengujian diperoleh hasil variabel e-wom, brand image dan brand trust secara simultan berpengaruh positif dan signifikan terhadap keputusan konsumen dengan nilai f hitung 41,919>2,71 (f hitung) dan nilai signifikansi 0,000. Secara parsial ewom dan brand image berpengaruh positif dan signifikan terhadap keputusan konsumen dengan nilai thitung 3,795 >1,99, 5,714 >1,99 dan signifikansinya 0,000. Sedangkan brand trust bernilai negatif dan tidak berpengaruh signifikan terhadap keputusan konsumen dengan nilai konsumen, ini berdasarkan hasil pengujian yang menunjukkan nilai thitung $-1,625<\mathrm{t}$ tabel 1,99 dan nilai signifikansi 1,08. Brand image memiliki pengaruh paling dominan terhadap keputusan konsumen karena memiliki pengaruh yang paling besar.
\end{abstract}

Kata Kunci: e-wom, Brand Image, Brand Trust, Keputusan Konsumen 


\section{PENDAHULUAN}

Bahasa inggris saat ini merupakan salah satu kebutuhan yang penting dalam menghadapi persaingan baik di dunia usaha maupun dunia pendidikan. Kemampuan seseorang dituntut untuk mampu mengimbangi kemajuan jaman yang selalu berubah-ubah setiap waktu, sehingga sejak memulai pendidikan di sekolah dasar sudah mulai diperkenalkan dengan bahasa inggris. Namun terkadang porsi pembelajaran di sekolah masih dirasakan kurang sehingga dirasa perlu adanya solusi alternative untuk mempelajari kemampuan berbahasa inggris agar lebih lancar dan baik yakni mencari lembaga kursus. Salah satu destinasi yang popular untuk memperdalam kemampuan berbahasa inggris adalah kampung inggris yang berada di desa pelem dan tulungrejo kecamatan pare kabupaten Kediri provinsi jawa timur (aminatul, 2018). Penyematan nama kampung inggris diawali oleh wartawan yang meliput di kawasan tersebut yang didasari oleh banyaknya lembaga kursus yang tersedia di kawasan tersebut, karena lebih dari seratus lembaga yang berdiri di sana yang dimana seluruh lembaga yang ada di kampung inggris diawasi langsung oleh BEC yang merupakan lembaga kursus bahasa inggris yang didirikan oleh Mr. Kalend Osen (al-jum'ah, 2018) sehingga kualitas dan mutu yang diberikan tiap-tiap lembaga terjamin. Dengan adanya banyak lembaga yang tersedia semakin banyak pula pilihan konsumen untuk memutuskan lembaga mana yang sesuai dengan keinginan mereka.

Keputusan konsumen berawal dari proses Pengenalan masalah, Pencarian informasi, Evaluasi alternative, dimana setelahnya Keputusan akan terbentuk yang kemudian dampak dari keputusan yang diambil akan dirasakan konsumen (Kotler \& Keller, 2016). Berawal dari kebutuhan konsumen tentang bagaimana memperdalam kemampuan berbahasa inggris, mereka melakukan pencarian informasi dan menemukan lembaga kursus di kampung inggris. Dengan banyaknya pilihan lembaga maka konsumen melakukan menggali informasi mengenai lembaga dari berbagai sumber seperti website, blog dan juga jejaring social yang dimana berbagai pendapat muncul sehingga konsumen dapat memutuskan pilihan lembaga mana yang akan dipilih. Ada banyak faktor yang mempengaruhi keputusan konsumen, beberapa diantaranya adalah E-WOM (Guo, Wang, \& Wu, 2020), brand image (Jalilvand \& Samiei, 2012) dan brand trust (Zhao, Huang, \& Su, 2019).

Word of Mouth adalah salah satu jenis pemasaran yang paling cepat dalam menyebarkan informasi, dimana komunikasi yang terjadi antara dua orang atau lebih mengenai produk barang atau jasa, dimana terjadi argument dan komentar tentang kualitas, model, kinerja dan lain-lain muncul dari seseorang yang mengalami. Informasi ini bisa bersifat positif maupun negative tergantung dari pengalaman yang pernah dirasakan oleh salah satu pihak. Dengan perkembangan teknologi yang semakin berkembang membuat orang lebih senang melakukan interaksi di social media seperti membagikan pengalaman pribadi tentang produk atau jasa yang dirasakan mereka. Berbagai ulasan yang diberikan, ada yang baik maupun tidak baik dapat di akses dengan cepat seiring perkembangan internet (Kotler \& Keller, 2009). 
Pengaruh E-WOM, Brand Image dan Brand Trust Terhadap Keputusan Konsumen (studi kasus pada lembaga kursus Fajar English Course Pare-Kediri)

Oleh karena itu lembaga kursus melakukan penyebaran informasi mulai dari teks, gambar, brosur, sampai video di akun media social mereka. Dengan pemanfaatan media elektronik inilah yang disebut dengan e-wom dimana social media yang dijadikan platform dalam melaksanakan penyebaran berita serta informasi. Akses yang mudah, biaya murah dan cepat tersebar serta lingkup penyebaran informasi yang sangat luas sehingga konsumen di berbagai tempat dapat mengenal dan mengetahui informasi mengenai lembaga tersebut.

Selain e-wom, Brand image juga menjadi salah satu hal yang menjadi pertimbangan konsumen. Sebab dengan adanya banyak pilihan lembaga kurus yang tersedia di kampung inggris membuat setiap lembaga harus memiliki suatu identitas atau citra merk yang berbeda diantara tempat lainnya. Citra merek yang positif akan membuat pelanggan menyukai suatu produk dengan merek yang bersangkutan dikemudian hari, sedangkan bagi produsen citra merek yang baik akan menghambat kegiatan pemasaran pesaing

Selain e-wom dan brand image faktor lain yang mempengaruhi keputusan memilih adalah brand trust dimana seorang konsumen akan membeli produk karena konsumen percaya dan yakin terhadap produk tersebut. Brand trust adalah perasaan aman yang diperoleh konsumen dalam interaksinya dengan merek yang didasarkan pada persepsi bahwa merek tersebut dapat diandalkan dan memenuhi kepentingan serta keselamatan konsumen. Trust didefinisikan sebagai persepsi konsumen mengenai reliabilitas yang didasarkan pada pengalaman atau serangkaian transaksi atau interaksi yang dikarakteristikkan oleh konfirmasi dari harapan atas kinerja produk dan kepuasan (Afandi, 2011:2). Dalam hal ini, peserta didik di Fajar English Course yang memutuskan memilih lembaga kursus bahasa inggris ini menaruh kepercayaan bahwa Fajar English Course dinilai mampu membimbing belajar bahasa inggris secara khusus berdasarkan pengalaman dan kepuasan peserta didik sebelumnya.

\section{KAJIAN LITERATUR}

\section{Electronic Word of Mouth}

Kemajuan teknologi internet menjadikan penyebaran word of mouth tidak terbatas pada komunikasi tatap muka, namun sudah berkembang melalui internet dan berbagai macam media sosial yang lebih dikenal dengan istilah electronic word of mouth. Electronic Word of Mouth merupakan pernyataan positif maupun negatif yang terbentuk dari adanya opini konsumen, calon konsumen maupun mantan konsumen dari sebuah produk yang dapat diakses oleh khalayak luas di dunia maya (Hennig-Thurau et al., 2004) dalam eWOM menjadi sebuah venue atau sebuah tempat yang sangat penting untuk konsumen memberikan opininya dan dianggap lebih efektif dibandingkan WOM offline, karena tingkat aksesibilitas dan jangkauannya yang lebih luas (Jalilvand 2012) dalam (Semuel dan Lianto, 2014). 
Penelitian yang dilakukan Thurau et al., dalam (Cahyono, Kusumawati, \& Kumadji, 2016) merefleksikan Electronic Word of Mouth (eWOM) melalui 8 dimensi, yaitu:

1. Platform Assistance /Bantuan Platform

2. Venting Negative Feelings / Melampiaskan Perasaan Negatif

3. Concern for Others / Kepedulian Terhadap Orang Lain

4. Extraversion/Positive Self-Enhancement /Peningkatan Diri Positif

5. Social Benefits / Manfaat Sosial

6. Economic Incentives /Insentif Ekonomi

7. Helping the Company / Membantu Perusahaan

8. Advice Seeking / Pencarian Saran

Pada masa kini, para konsumen menggunakan media sosial sebagai sarana berbagi pengalaman yang mereka alami dan informasi yang mereka miliki mengenai sebuah merk, produk, jasa, ataupun layanan-layanan yang ada. Selain itu para konsumen juga kini menggunakan pengalaman orang lain sebagai referensi mereka dalam pembuatan keputusan untuk membeli sebuah produk (Akbar \& Sunarti, 2018).

Kekuatan konten dan percakapan yang terjadi di dalam sosial media mendorong banyak perusahaan yang memanfaatkan sebagai alat komunikasi dan pemasaran mereka. Melalui media sosial perusahaan dapat mempromosikan sebuah produk dan membentuk komunitas atau group online untuk konsumen yang menyukai merek yang digunakan. Adanya komunitas atau group online tersebut akan memungkinkan terjadinya suatu interaksi sosial secara elektronik yang akan mendorong terjadinya electronic word of mouth. Oleh karenanya banyak perusahaan menyadari kekuatan dari electronic word of mouth di media sosial.

\section{Brand Image}

Perusahaan harus memiliki merek yang berbeda dengan pesaingnya, begitu pula dengan citra merek yang tertanam di benak pelanggan. Karena citra merek merupakan salah satu hal yang dilihat pertama kali oleh pelanggan sebelum melakukan pembelian atau pemilihan produk. Menurut Kotler dan Keller (2012:248) "Brand Imagery describes the extrinsic properties of the product or service, including the ways in which the brand attempts to meet customers psychological or social needs". Brand Image menggambarkan sifat ekstrinsik dari suatu produk atau jasa termasuk cara dimana merek berusaha memenuhi kebutuhan psikologis atau sosial pelanggan.

Citra merek merupakan pemahaman pelanggan mengenai merek secara keseluruhan. Kepercayaan pelanggan terhadap suatu merek tertentu dan bagaimana pelanggan memandang suatu merek. Citra merek yang positif akan membuat pelanggan menyukai suatu produk dengan merek yang bersangkutan dikemudian hari, sedangkan bagi produsen citra merek yang baik akan menghambat kegiatan pemasaran pesaing. Kotler dan Keller (2012:768) mendefinisikan brand image "Preception and beliefs held by consumers. As reflected in the associations held in consumers memory". sebagai 
Pengaruh E-WOM, Brand Image dan Brand Trust Terhadap Keputusan Konsumen (studi kasus pada lembaga kursus Fajar English Course Pare-Kediri)

sekumpulan persepsi dan kepercayaan yang dimiliki oleh pelanggan terhadap suatu brand yang direfleksikan melalui asosiasi-asosiasi yang ada dalam ingatan pelanggan.

Ketika suatu brand image telah mampu untuk membangun karakter produk dan memberikan value proposition, kemudian menyampaikan karakter produk tersebut kepada pelanggannya secara unik, berarti brand tersebut telah memberikan suatu kekuatan emosional lebih dari kekuatan rasional yang dimiliki oleh produk tersebut. Hal ini akan membuat pelanggan mengasosiasikan hal positif dalam pikirannya ketika mereka memikirkan brand tersebut.

\section{Dimensi dan Indikator Citra Merek ( Brand Image ).}

Menurut Keller (2013:97) dimensi-dimensi utama membentuk citra sebuah merek tertuang dalam berikut ini:

1. Brand Identity (identitas Merek)

Brand identity merupakan identitas fisik yang berkaitan dengan merek atau produk tersebut sehingga pelanggan mudah mengenali dan membedakannya dengan merek atau produk lain, seperti logo, warna, kemasan, lokasi, identitas perusahaan yang memayungi, slogan, dan lainlain.

2. Brand Personality (Personalitas Merek).

Brand personality adalah karakter khas sebuah merek yang membentuk kepribadian tertentu sebagaimana layaknya manusia, sehingga khalayak pelanggan dengan mudah membedakannya dengan merek lain dalam kategori yang sama, misalnya karakter tegas, kaku, berwibawa, nigrat, atau murah senyum, hangat, penyayang, berjiwa sosial, atau dinamis, kreatif, independen, dan sebagainya.

3. Brand Association (Asosiasi Merek).

Brand Association adalah hal-hal spesifik yang pantas atau selalu dikaitkan dengan suatu merek, bisa muncul dari penawaran unik suatu produk, aktivitas yang berulang dan konsisten misalnya dalam hal sponsorship atau kegiatan social resposibility, isu-isu yang sangat kuat berkaitan dengan merek tersebut, ataupun person, simbol-simbol dan makna tertentu yang sangat kuat melekat pada suatu merek.

4. Brand Attitude and Behavior (sikap dan perilaku merek).

Brand attitude and behavior adalah sikap atau perilaku komunikasi dan interaksi merek dengan pelanggan dalam menawarkan benefit-benefit dan nilai yang dimilikinya. Attitude and behavior mencakup sikap dan perilaku pelanggan, aktivitas dan atribut yang melekat pada merek saat berhubungan dengan khalayak pelanggan, termasuk perilaku karyawan dan pemilik merek.

5. Brand Benefit and Competence (Manfaat dan Keunggulan Merek).

Brand benefit and competence merupakan nilai-nilai dan keunggulan khas yang ditawarkan oleh suatu merek kepada pelanggan yang membuat pelanggan dapat merasakan manfaat karena kebutuhan, keinginan, 
mimpi, dan obsesinya terwujudkan oleh apa yang ditawarkan tersebut.

Menurut Kotler dan Keller (2012:347), citra merek dapat dilihat dari:

1. Keunggulan asosiasi merek, salah satu faktor pembentuk brand image adalah keunggulan produk, dimana produk tersebut unggul dalam persaingan.

2. Kekuatan asosiasi merek, setiap merek yang berharga mempunyai jiwa, suatu kepribadian khusus adalah kewajiban mendasar bagi pemilik merek untuk dapat mengungkapkan, mensosialisasikan jiwa/kepribadian tersebut dalam satu bentuk iklan, ataupun bentuk kegiatan promosi dan pemasaran lainnya. Hal itulah yang akan terus menerus menjadi penghubung antara produk/merek dengan pelanggan. dengan demikian merek tersebut akan cepat dikenal dan akan tetap terjaga ditengah-tengah maraknya persaingan. Membangun popularitas sebuah merek menjadi merek yang terkenal tidaklah mudah. Namun demikian, popularitas adalah salah satu kunci yang dapat membentuk brand image pada pelanggan.

3. Keunikan asosiasi merek, merupakan keunikan-keunikan yang dimiliki oleh produk tersebut.

Berdasarkan uraian diatas, maka indikator dari citra merek yang digunakan dalam penelitian ini adalah menurut (Kotler \& Keller, 2012) yaitu Brand Identity (identitas Merek), Brand Personality (Personalitas Merek), Brand Association (Asosiasi Merek), Brand Attitude dan Behavior (sikap dan perilaku merek), Brand Benefit and Competence (Manfaat dan Keunggulan Merek)

\section{Brand Trust}

Brand trust merupakan faktor yang dapat mempengaruhi keputusan pembelian konsumen. Kepercayaan pelanggan pada merek (brand trust) didefinisikan sebagai keinginan pelanggan untuk bersandar pada sebuah merek dengan resiko-resiko yang dihadapi karena ekspektasi terhadap merek itu akan menyebabkan hasil yang positif (Lau \& Lee, 1999, p. 344) dalam (Adiwidjaja dan Tarigan, 2017).

Menurut American Marketing Association, merek adalah nama, istilah, tanda, simbol, rancangan, atau kombinasi dari hal-hal tersebut, yang dimaksudkan untuk mengidentifikasi barang atau jasa dari seorang atau kelompok penjual dan untuk membedakannya dari produk pesaing (Kotler dan Keller, 2012:460). Penggunaan konsisten suatu merek, simbol, atau logo membuat merek tersebut segera dapat dikenali oleh konsumen sehingga segala sesuatu yang berkaitan dengannya tetap diingat. Dengan demikian, suatu merek dapat mengandung tiga hal, yaitu sebagai berikut:

a. Menjelaskan apa yang dijual perusahaan.

b. Menjelaskan apa yang dijalankan oleh perusahaan.

c. Menjelaskan profil perusahaan itu sendiri.

Menurut Delgado yang dikutip oleh (Wirdaini, 2018), brand trust (kepercayaan merek) merupakan harapan akan kehandalan dan intensi 
Pengaruh E-WOM, Brand Image dan Brand Trust Terhadap Keputusan Konsumen (studi kasus pada lembaga kursus Fajar English Course Pare-Kediri)

merek. Ada dua indikator variabel yang mempengaruhi brand trust (kepercayaan merek) yaitu:

1. Brand Reliability

Brand reliability merupakan kehandalan merek yang bersumber pada keyakinan konsumen bahwa produk tersebut mampu memenuhi nilai yang dijanjikan atau dengan kata lain persepsi bahwa merek tersebut mampu memenuhi kebutuhan dan memberikan kepuasan.

Brand reliability juga merupakan hal yang esensial bagi terciptanya kepercayaan terhadap merek karena kemampuan merek dapat memenuhi nilai yang dijanjikan dan akan membuat konsumen menaruh rasa yakin serta mendapatkan apa yang dibutuhkan untuk keluar dari perasaan terancam.

\section{Brand Intention}

Brand intention merupakan minat pada merek yang didasarkan pada keyakinan konsumen bahwa merek tersebut mampu mengutamakan kepentingan konsumen ketika masalah dalam konsumsi produk muncul secara tidak terduga. Dengan kata lain, brand intention mencerminkan perasaan aman dari seorang individu terhadap suatu merek.

Kedua komponen kepercayaan merek bersandar pada penilaian konsumen yang subyektif atau didasarkan pada persepsi masing-masing konsumen terhadap manfaat yang dapat diberikan produk atau merek.

\section{Keputusan Pembelian}

Keputusan konsumen dalam melakukan pembelian suatu produk merupakan suatu tindakan yang lazim dijalani oleh setiap individu konsumen ketika mengambil keputusan membeli. Keputusan membeli atau tidak membeli merupakan bagian dari unsur yang melekat pada diri individu konsumen yang disebut behavior dimana ia merujuk kepada tindakan fisik yang nyata. (Alma, 2011) berpendapat bahwa keputusan pembelian sebagai suatu keputusan konsumen yang dipengaruhi oleh ekonomi keuangan, teknologi, politik, budaya, produk, harga, lokasi, promosi, physical evidence, people dan process, sehingga membentuk suatu sikap pada konsumen untuk mengolah segala informasi dan mengambil kesimpulan berupa response yang muncul produk apa yang akan dibeli. Menurut Kotler dan Keller yang dialih bahasakan oleh (Tjiptono, 2014) keputusan pembelian sebagai tahap keputusan dimana konsumen secara aktual melakukan pembelian suatu produk. Berdasarkan definisi diatas dapat disimpulkan bahwa keputusan pembelian merupakan suatu keputusan yang dipengaruhi oleh beberapa faktor yang akan membuat konsumen secara aktual mempertimbangkan segala sesuatu dan pada akhirnya konsumen membeli produk yang paling mereka sukai.

Indikator keputusan pembelian menurut Kotler dan Keller yang dialih bahasakan oleh (Tjiptono, 2014) menjelaskan bahwa dalam mengukur keputusan pembelian, konsumen selalu mempertimbangkan pilihan produk, 
merek, penyalur, waktu pembelian, dan jumlah pembelian yang sesuai dengan kebutuhan konsumen terhadap suatu barang.

\section{Kerangka Berpikir}

Dari teori diatas dapat digambarkan kerangka berpikir dari penelitian ini sebagai berikut :

\section{Gambar 1. Kerangka berpikir}

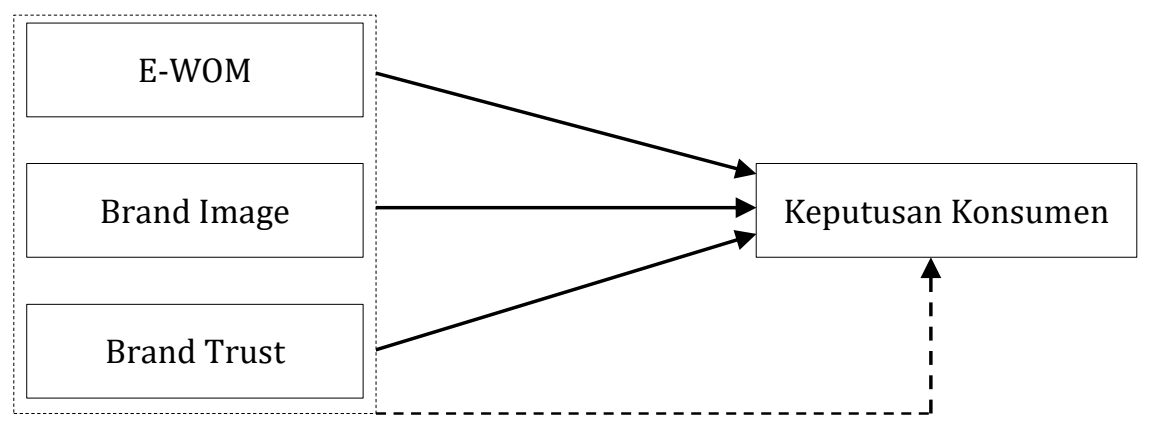

Sumber : data diolah 2019

\section{Hipotesis}

Dari kerangka berpikir diatas dapat diuraikan hipotesis sebagai berikut :

H1 : E-WOM berpengaruh signifikan terhadap keputusan konsumen

H2 : Brand Image berpengaruh signifikan terhadap Keputusan Konsumen

H3 : Brand Trust berpengaruh signifikan terhadap keputusan konsumen

H4 : E-WOM, Brand Image dann Brand Trust Berpengaruh Signifikan Terhadap Keputusan Konsumen

\section{METODE PENELITIAN}

Penelitian ini menggunakan pendekatan Kuantitatif yang dimana berkaitan dengan keputusan konsumen dalam memilih fajar English course sebagai tempat untuk melakukan kursus bahasa inggris. Populasi dalam penelitian ini adalah peserta kursus di lembaga kursus fajar English course pada bulan agustus-september 2019 sejumlah 89 orang. Oleh karena populasi kurang dari 100 maka diambil keseluruhan untuk dijadikan sampel (Arikunto, 2010). Jenis data yang dipakai dalam penelitian ini adalah data primer dan sekunder yang bersumber dari kuesioner, observasi dan wawancara serta literature review.

\section{Definisi Operasional Variabel}

Dalam penelitian ini terdapat 2 jenis variabel, yakni variabel independen (X) dan variabel dependen (Y). Untuk memperjelas masing-masing variabel, maka definisi operasionalnya diuraikan sebagai berikut :

\section{Electronic Word of Mouth (X1)}

Indikator variabel E-WOM menurut thurau dalam (Cahyono et al., 2016) antara lain :

\section{Platform Assistance /Bantuan Platform}


Pengaruh E-WOM, Brand Image dan Brand Trust Terhadap Keputusan Konsumen (studi kasus pada lembaga kursus Fajar English Course Pare-Kediri)

2. Venting Negative Feelings / Melampiaskan Perasaan Negatif

3. Concern for Others / Kepedulian Terhadap Orang Lain

4. Extraversion/Positive Self-Enhancement /Peningkatan Diri Positif

5. Social Benefits / Manfaat Sosial

6. Economic Incentives /Insentif Ekonomi

7. Helping the Company / Membantu Perusahaan

8. Advice Seeking / Pencarian Saran

Brand Image (X2)

Indikator variabel brand image menurut (Kotler \& Keller, 2012) antara lain :

1. Brand Identity (identitas Merek),

2. Brand Personality (Personalitas Merek),

3. Brand Association (Asosiasi Merek),

4. Brand Attitude dan Behavior (sikap dan perilaku merek),

5. Brand Benefit and Competence (Manfaat dan Keunggulan Merek)

Brand Trust (X3)

Indikator variabel brand trust menurut Delgado yang dikutip (Wirdaini, 2018) antara lain :

1. Brand reliability

2. Brand intention

Keputusan Konsumen (Y)

Indikator variabel keputusan pembelian menurut Kotler dan Keller yang dialih bahasakan oleh (Tjiptono, 2014), antara lain :

1. pilihan produk,

2. merek,

3. penyalur,

4. waktu pembelian, dan

5. jumlah pembelian yang sesuai dengan kebutuhan konsumen terhadap suatu barang.

\section{Metode Analisis}

Pengujian yag dilakukan dalam penelitian ini menggunakan beberapa tahap antara lain uji validitas dan reliabilitas instrumen, analisis regresi berganda, pengujian hipotesis dilakukan dengan uji $f$ dan uji $t$ serta koefisien determinasi.

\section{PEMBAHASAN}

Uji Validitas dan Reliabilitas

Berdasarkan hasil pengujian hasil penyebaran kuesioner terhadap 89 responden diperoleh hasil bahwa seluruh item kuesioner memiliki nilai $r$ hitung lebih besar dari 0,212 (rtabel) sehingga seluruh kuesioner dinyatakan valid. Selanjutnya dari hasil perhitungan uji reliabilitas diperoleh hasil 
perhitungan untuk masing-masing variabel yaitu e-wom 0.723 , brand image 0,770 , brand trust 0,790 , dan keputusan konsumen 0,766 dimana seluruhnya lebih besar dari 0,6. Sehingga seluruh item dinyatakan reliabel.

Uji Hipotesis

Analisis Regresi Berganda

Analisis ini dipakai untuk mengetahui peran variabel independen (X) terhadap variabel dependen (Y) dimana hasil pengolahan menggunakan software spss v22 sebagai berikut:

Tabel 1

Coefficients $^{\mathbf{a}}$

\begin{tabular}{|c|c|c|c|c|c|c|}
\hline \multirow{2}{*}{\multicolumn{2}{|c|}{ Model }} & \multicolumn{2}{|c|}{$\begin{array}{c}\text { Unstandardized } \\
\text { Coefficients }\end{array}$} & \multirow{2}{*}{$\begin{array}{c}\begin{array}{c}\text { Standardized } \\
\text { Coefficients }\end{array} \\
\text { Beta }\end{array}$} & \multirow[b]{2}{*}{$\mathrm{t}$} & \multirow[b]{2}{*}{ Sig. } \\
\hline & & $\mathrm{B}$ & Std. Error & & & \\
\hline \multirow[t]{4}{*}{1} & (Constant) & 4.898 & 1.956 & & 2.504 & .014 \\
\hline & e-wom & .256 & .068 & .347 & 3.795 & .000 \\
\hline & Brand Image & .575 & .101 & .512 & 5.714 & .000 \\
\hline & Brand Trust & -.230 & .142 & -.115 & -1.625 & .108 \\
\hline
\end{tabular}

a. Dependent Variable: Keputusan Konsumen

Sumber : data diolah 2019

1. Variabel e-wom (X1) terhadap keputusan pembelian yang hasil koefisien sebesar 0,256, menggambarkan bahwa e-wom mempunyai nilai positif artinya e-wom mempunyai peran terhadap keputusan pembelian dan apabila e-wom ditingkatkan satu satuan sehingga akan berperan juga terhadap peningkatan keputusan pembelian

2. Variabel brand image (X2) terhadap keputusan pembelian yang hasil koefisien sebesar 0,575, menggambarkan bahwa brand image mempunyai nilai positif artinya brand image mempunyai peran terhadap keputusan pembelian dan apabila brand image ditingkatkan satu satuan sehingga akan berperan juga terhadap peningkatan keputusan pembelian

3. Variabel brand trust (X3) terhadap keputusan konsumen yang hasil koefisien sebesar -0,230, menggambarkan bahwa brand trust mempunyai nilai negatif artinya brand trust tidak mempunyai peran terhadap kinerja karyawan dan apabila brand trust ditingkatkan satu satuan tidak akan berperan terhadap peningkatan keputusan pembelian.

\section{Uji Hipotesis}

\section{Uji t}

Pengujian ini dilakukan dengan membandingkan nilai dari t hitung dengan $t$ tabel dimana apabila nilai thitung $>$ ttabel atau sig $<0,05$ maka hipotesis diterima, sebaliknya jika thitung < ttabel atau sig $>0,05$ maka hipotesis ditolak. (ttabel 89 responden $=1,99$ ) 
Pengaruh E-WOM, Brand Image dan Brand Trust Terhadap Keputusan Konsumen (studi kasus pada lembaga kursus Fajar English Course Pare-Kediri)

Berdasarkan tabel 1 diperoleh hasil sebagai berikut :

1. 3,795 > 1,99 ini menunjukkan bahwa hipotesis yang menyatakan bahwa ewom berpengaruh signifikan terhadap keputusan pembelian diterima

2. 5,714>1,99 ini menunjukkan bahwa hipotesis yang menyatakan bahwa brand image berpengaruh signifikan terhadap keputusan pembelian diterima

3. $-1,625<1,99$ ini menunjukkan bahwa hipotesis yang menyatakan brand trust berpengaruh signifikan terhadap keputusan pembelian ditolak

\section{Uji f}

Pengujian ini dilakukan dengan membandingkan nilai fhitung dengan ftabel, jika fhitung $>$ ftabel atau sig $<0,05$ maka hipotesis diterima, sebaliknya jika fhitung $<$ ftabel atau sig $>0,05$ maka hipotesis ditolak.

Tabel 2

\begin{tabular}{|c|c|c|c|c|c|c|}
\hline \multicolumn{2}{|c|}{ Model } & $\begin{array}{c}\text { Sum of } \\
\text { Squares }\end{array}$ & $\mathrm{df}$ & Mean Square & $\mathrm{F}$ & Sig. \\
\hline \multirow[t]{3}{*}{1} & Regression & 471.508 & 3 & 157.169 & 41.919 & $.000^{\mathrm{b}}$ \\
\hline & Residual & 318.694 & 85 & 3.749 & & \\
\hline & Total & 790.202 & 88 & & & \\
\hline
\end{tabular}

a. Dependent Variable: Keputusan Konsumen

b. Predictors: (Constant), Brand Trust, Brand Image, e-wom

Sumber : data diolah 2019

Berdasarkan tabel 2 diperoleh hasil bahwa 41,919>2,71 (fhitung) yang berarti bahwa hipotesis yang menyatakan bahwa e-wom, brand image dan brand trust berpengaruh signifikan terhadap keputusan pembelian diterima.

\section{Koefisien Determinasi}

Pengujian ini dilakukan untuk mengetahui variasi variabel independen (X) terhadap variabel dependen (Y) yang disajikan dalam tabel sebagai berikut:

\section{Tabel 3}

\begin{tabular}{|l|r|r|r|r|}
\multicolumn{1}{c|}{ Model Summary } \\
Model & $\mathrm{R}$ & $\mathrm{R}$ Square & \multicolumn{1}{c|}{$\begin{array}{c}\text { Adjusted R } \\
\text { Square }\end{array}$} & $\begin{array}{c}\text { Std. Error of } \\
\text { the Estimate }\end{array}$ \\
\hline 1 & $.772^{\mathrm{a}}$ & .597 & .582 & 1.936 \\
\hline
\end{tabular}

a. Predictors: (Constant), Brand Trust, Brand Image, e-wom

Sumber : Data diolah 2019

Berdasarkan tabel 3 diatas diperoleh nilai koefisien determinasi atau adjusted $r$ square sebesar 0,582 yang berarti bahwa kemampuan variabel ewom, brand image dan brand trust dalam menjelaskan variabel keputusan konsumen sebesar 58,2\%. Sedangkan sisanya sebesar 41,8\% dijelaskan oleh 
variabel lain yang tidak diamati dalam penelitian ini, sedangkan tingkat korelasinya sedang.

\section{E-wom berpengaruh signifikan terhadap keputusan pembelian}

berdasarkan hasil penelitian ini membuktikan bahwa electronic word of mouth berpengaruh signifikan terhadap keputusan konsumen. Dibuktikan dengan hasil pengujian thitung sebesar 3,795 >1,99 ttabel. Artinya seluruh perntanyaan yang diberikan terhadap responden sudah dirasa sesuai dengan apa yang mereka alami dimana penyebaran informasi melalui media social dianggap paling efektif daripada interaksi secara tatap muka dan tidak terbatas di suatu tempat tertentu. Hasil ini didukung oleh penelitian (Jalilvand \& Samiei, 2012) dan (Ruhamak, Vitasmoro, \& Rahmadi, 2018) yang menyatakan bahwa Electronic Word Of Mouth (EWOM) menjadi sebuah venue atau sebuah tempat yang sangat penting untuk konsumen memberikan opininya dan dianggap lebih efektif dibandingkan WOM offline, karena tingkat aksesibilitas dan jangkauannya yang lebih luas.

\section{Brand Image berpengaruh signifikan terhadap keputusan pembelian}

berdasarkan hasil penelitian ini membuktikan bahwa brand image berpengaruh signifikan terhadap keputusan konsumen. Dibuktikan dengan hasil perhitungan thitung 5,714>1,99 ttabel, ini menunjukkan bahwa citra lembaga yang berada di kawasan kampung inggris tidak perlu diragukan lagi, proses interaksi yang terjadi saat proses kegiatan pembelajaran sangat berkesan sehingga tidak ada keraguan saat konsumen memilih tempat tersebut. Hal ini didukung penelitian (M Dian Ruhamak \& Rahayu, 2016) yang menyatakan bahwa brand image berpengaruh signifikan terhadap keputusan konsumen dalam memilih kursus di DEC pare .

\section{Brand Trust tidak berpengaruh signifikan terhadap keputusan konsumen}

berdasarkan hasil penelitian ini membuktikan bahwa brand trust tidak berpengaruh signifikan terhadap keputusan konsumen. Dibuktikan dengan hasil perhitungan thitung -1,625 < 1,99 ttabel, ini menunjukkan bahwa kepercayaan konsumen terhadap keputusan konsumen tidak terbatas hanya pada satu lokasi lembaga saja. Konsumen menganggap seluruh lembaga yang ada dikampung inggris tidak ada yang meragukan, tidak memandang apakah lembaga itu besar maupun kecil. Ini tidak mendukung penelitian (Mamahit, Soegoto, \& Tumbuan, 2015) yang menyatakan bahwa brand trust berpengaruh terhadap keputusan konsumen.

\section{Variabel yang paling dominan}

berdasarkan hasil pengujian membuktikan brand image memiliki pengaruh yang paling besar terhadap keputusan konsumen karena memiliki nilai $\mathrm{t}$ hitung 5,714 paling besar diantara variabel lainnya, nilai signifikan 0,000 menunjukkan bahwa semakin kecil nilai signifikansinya maka semakin besar pengaruh brand image terhadap keputusan konsumen. 
Pengaruh E-WOM, Brand Image dan Brand Trust Terhadap Keputusan Konsumen (studi kasus pada lembaga kursus Fajar English Course Pare-Kediri)

\section{SIMPULAN}

Dari pengujian diatas dapat ditarik kesimpulan antara lain sebagai berikut:

1. Terdapat pengaruh positif dan signifikan antara variabel electronic word of mouth terhadap keputusan konsumen, ini berdasarkan hasil pengujian yang menunjukkan nilai thitung variabel e-wom 3,795 > ttabel 1,99 dan nilai signifikansi 0,000

2. Terdapat pengaruh positif dan signifikan antara variabel Brand Image terhadap keputusan konsumen, ini berdasarkan hasil pengujian yang menunjukkan nilai thitung variabel Brand Image 5,714 > ttabel 1,99 dan nilai signifikansi 0,000

3. Tidak terdapat pengaruh positif dan signifikan antara variabel Brand Trust terhadap keputusan konsumen, ini berdasarkan hasil pengujian yang menunjukkan nilai thitung variabel Brand Trust $-1,625<$ ttabel 1,99 dan nilai signifikansi 1,08 .

4. Terdapat pengaruh positif dan signifikan antara variabel e-wom, brand image dan brand trust secara bersama-sama terhadap keputusan konsumen. Ini berdasarkan hasil pengujian yang menunjukkan nilai fhitung 41,919>2,71 (fhitung) dan nilai signifikansi 0,000.

5. Berdasarkan perhitungan membuktikan brand image memiliki pengaruh yang paling besar terhadap keputusan konsumen karena memiliki nilai $\mathrm{t}$ hitung 5,714 paling besar diantara variabel lainnya, nilai signifikan 0,000 menunjukkan bahwa semakin kecil nilai signifikansinya maka semakin besar pengaruh brand image terhadap keputusan konsumen.

\section{DAFTAR PUSTAKA}

Akbar, M. J. C., \& Sunarti, S. (2018). Pengaruh Electronic Word Of Mouth Terhadap Keputusan Pembelian ( Survei pada Konsumen Restoran Sushi Tei Kelapa Gading ). Jurnal Administrasi Bisnis (JAB)|, 60(3), 45-51.

al-jum'ah, ais nurbiyah. (2018). Kalend Osen, Kampung Inggris, dan Kemudrtadan Berbahasa | Locita. Retrieved July 31, 2019, from https://locita.co/tokoh/siapa/kalend-osen-kampung-inggris-dankemurtadan-berbahasa

Alma, B. (2011). Manajemen pemasaran dan pemasaran jasa.

aminatul, anggun putri. (2018). Silaturahmi ke Mr. Kalend Osen (BEC Kampung Inggris), Sang Perintis Kampung Inggris - Blog Bias Education. Retrieved July 31, 2019, from http://blog.bias-pare.com/silaturahmi-kemr-kallend-osen-perintis-kampung-inggris/

Arikunto, S. (2010). Prosedur penelitian. Jakarta: rineka cipta.

Cahyono, F. D., Kusumawati, A., \& Kumadji, S. (2016). Analisis Faktor-Faktor Pembentuk Electronic Word-of-Mouth (e-WOM) dan Pengaruhnya Terhadap Minat Beli (Survei Pada Followers Akun Instagram @saboten_shokudo). Jurnal Administrasi Bisnis (JAB), 37(1), 148-157. https://doi.org/10.1038/ismej.2013.172

Guo, J., Wang, X., \& Wu, Y. (2020). Positive emotion bias: Role of emotional 
content from online customer reviews in purchase decisions. Journal of Retailing and Consumer Services, 52(October 2018), 101891. https://doi.org/10.1016/j.jretconser.2019.101891

Jalilvand, M. R., \& Samiei, N. (2012). The effect of electronic word of mouth on brand image and purchase intention: An empirical study in the automobile industry in Iran. Marketing Intelligence and Planning, 30(4), 460-476. https://doi.org/10.1108/02634501211231946

Kotler, P., \& Keller, K. L. (2009). Marketing Management 13th Edition.

Kotler, P., \& Keller, K. L. (2012). Global Marketing Management 14 th Edition. Management Decision (14 th, Vol. 48). Prentice Hall/Financial Times. https://doi.org/10.1108/00251741011076816

Kotler, P., \& Keller, K. L. (2016). Marketing Management 15th Global Edition. England: Pearson Educationn Limited. Retrieved from https://app.luminpdf.com/viewer/99cAGZGug6i5d4dsL

Mamahit, P., Soegoto, A. S., \& Tumbuan, W. A. (2015). Pengaru Brand Image, Brand Trust \& Quality Mobil Toyota All New Yaris Pada. Jurnal Berkala Ilmiah Efisiensi, 15(05).

Ruhamak, Muhammad Dian, Vitasmoro, P., \& Rahmadi, A. N. (2018). The Influence of Testimonial, Social Media-based Promotions and Electronic Word of Mouth toward Purchase Intention. Proceedings of the Annual Conference on Social Sciences and Humanities (ANCOSH), 1(1), 78-81.

Ruhamak, M Dian, \& Rahayu, B. (2016). Pengaruh Word of Mouth Terhadap Purchase Intention Melalui Brand Image Pada Lembaga Kursus Bahasa Inggris Dynamic English Course Pare. EKONIKA: Jurnal Ekonomi Universitas Kadiri, 1(2).

Tjiptono, F. (2014). Pemasaran Jasa-Prinsip, Penerapan, dan Penelitian. Yogyakarta: Andi Offset.

Wirdaini, M. (2018). Pengaruh brand image, brand trust, promosi dan word of mouth terhadap proses keputusan pembelian pada konsumen toko online muslimarket. com di Universitas Islam Negeri Syarif Hidayatullah Jakarta. Jakarta: Fakultas Ekonomi dan Bisnis UIN Syarif Hidayatullah.

Zhao, J., Huang, J., \& Su, S. (2019). Journal of Retailing and Consumer Services The e ff ects of trust on consumers ' continuous purchase intentions in C2C social commerce : A trust transfer perspective. Journal of Retailing and Consumer Services, 50(October 2018), 42-49. https://doi.org/10.1016/j.jretconser.2019.04.014 